\title{
Pharyngeal Airway Dimension in Different Types of Malocclusion
}

\author{
Ashwin Kumar.V ${ }^{1}$, Aravind Kumar ${ }^{2}$, Sivaram Subbiah ${ }^{3}$, Senkutvan R.S ${ }^{1}$ \\ ${ }^{1}$ Madha Dental College, Kundrathur, Chennai \\ ${ }^{2}$ Saveetha Dental College, Velapanchavadi \\ ${ }^{3}$ Penang International Dental College, Malaysia
}

\begin{abstract}
Objective: To assess the pharyngeal airway dimension in different types of malocclusion. Materials and_Methods: Literature was searched through PubMed, Web of Science, Embase, and All EBM Reviews. The inclusion criteria consisted of studies written in English; published in the past three decades; concerning the pharyngeal airway dimension in different types of malocclusion. Results: Our search strategy identified (PUBMED -22, AND MeSH -22) titles and abstracts of studies which were independently assessed. We also ran a free text search on Google Scholar for any further potentially eligible trials which resulted in the identification of 1 published. Full text copies of these studies were obtained from the Internet, and were then subjected to further assessment. We also checked the bibliographical references of these papers for any relevant studies and found all the included articles were found through electronic search. Conclusion: The pharyngeal airway dimensions are subjected to change with different malocclsuion and Narrow pharyngeal airway space is one of the predisposing factors for mouth breathing and obstructive sleep apnoea.
\end{abstract}

Keywords: pharyngeal airway dimension, malocclusion and Pharynx

Cite This Article: Ashwin Kumar.V, Aravind Kumar, Sivaram Subbiah, and Senkutvan R.S, "Pharyngeal Airway Dimension in Different Types of Malocclusion." International Journal of Dental Sciences and Research, vol. 2, no. 4A (2014): 7-11. doi: 10.12691/ijdsr-2-4A-3.

\section{Introduction}

The upper and lower airway has always been an area of interest because the oropharyngeal and nasopharyngeal structures play important roles in the growth and development of the craniofacial complex.

Pharyngeal space size is determined primarily by relative growth and size of the soft tissues surrounding the dentofacial skeleton.

From adulthood to older age (20-50 years of age), the nasopharyngeal skeleton may change. Many reports have demonstrated a relationship between various malocclusion patterns and variations in the size and form of the pharyngeal airway.

\section{Methods}

Criteria for considering studies for this review:

\subsection{Types of Studies}

Studies evaluated through lateral cephalogram and cone beam computed tomography was selected. The study selected were meeting the inclusion criteria.

\subsection{Types of Participants}

The participants in the study selected were healthy individuals. They had no history of orthodontic treatment or any pathological disorder. Syndrome and cleft patients were not included in the study.

\subsection{Search Methods for Identification of Studies}

\subsubsection{Electronic Searches}

For the identification of studies included or considered for this review, detailed search strategies were developed for each database to be searched.

We searched the following databases in July 2011: (PUBMED Medline 1950 to July 2011), MEDLINE (1950 to july 2011); SCIENCE DIRECT (1980 to July 2011) and MeSH.

\subsubsection{Hand Searches}

- All the included articles were available through electronic search. Hence no hand searches were done for this review.

A search for existing meta-analyses and non-Cochrane systematic reviews was also performed.

\subsection{Data Collection and Analysis}

Selection of studies: The articles were assessed independently by going through the titles and the abstracts of studies which were identified in the searches. Full copies of all relevant and potentially relevant study, those appearing to meet the inclusion criteria, or for which there were insufficient data in the title and abstract to make a clear decision, were obtained. The full text papers were 
assessed independently and any disagreement on the eligibility of trials was resolved through discussion and consensus.

\subsection{Data extraction and Management}

In the event that future studies are identified and included in updates, the following methods of data extraction and management will apply.

Study details will be collected using a pre-determined form designed for this purpose and entered into the 'Characteristics of included studies' table.

The following details will be extracted:

1. Title of the article: The title mentioned will be mentioned in the table.

2. Journal and year: The searched journal name will be mentioned.

3. Study design: Whether the study used Lateral Cephalogram ,or CBCT

4. Materials and methods:

- The no of participants.

- Age

- Sex

- Sample size

Results: primary outcome of the study mentioned, Secondary outcome also mentioned if published.6 No of citations referred: The number of citations referred in the study/article will be mentioned.

\section{Results}

\subsection{Results of the Search}

Our search strategy identified (PUBMED -22, AND $\mathrm{MeSH}$-22) titles and abstracts of studies which were independently assessed.

We also ran a free text search on Google Scholar for any further potentially eligible trials which resulted in the identification of 1 published-Comparison of upper and lower pharyngeal airway space in class II high and low angle cases(Pak dental journal Liffat batool).

Full text copies of these studies were obtained from the Internet, and were then subjected to further assessment. We also checked the bibliographical references of these papers for any relevant studies and found all the included articles were found through electronic search.

\subsection{Excluded Studies}

After electronic search and hand search, these articles were rejected after going through the full article. Lateral cepahalometric analysis of pharyngeal airway affected by head posture was rejected since it focused on only different head posture than comparing the relationship with different skeletal patterns.

Cephalometric evaluation of upper airway and its measurement article was excluded since this study reported about the important cephalometric measurement [21]. They did not compare the airway dimension with different skeletal pattern.

"Similarly" A comparitive study of upper airway among different skeletal craniofacial patterns in non snoring Chinese children" [22] was excluded-where only predisposing factor for obstruction were examined.
Nasopharyngeal and facial dimension of different morphological pattern by Murilo Fernando [23]. The study did not compare the pharyngeal airway dimension of different malocclusion [21,22,23,24].

\section{CLASS I NORMAL SUBJECTS VS CLASS I MALOCCLUSION:}

Studies were done among Class I Malocclusion for assessing the pharyngeal airway dimensions.

MARTIN AND MULLES [8] did a cephalometric study to assess nasopharyngeal soft-tissue patterns in patients with ideal occlusion. A sample of 91 patients was selected with ideal occlusion. A new line of investigation were introduced for measuring the pharyngeal airway width.

YOSHIHIKO Et Al [17] did a Pharyngeal airway dimensions were evaluated within class I malocclusion by comparing among normal occlusion and progathism patients. 25 girls with prognathism and 15 children with normal occlusion were selected for the study. They found that the Lower pharyngeal airway was wider as a result of prognathism maxilla and mandible.

SimilarlyFARUK [16] found out the Orofacial airway dimensions in subjects with Class I malocclusion and different growth patterns. Lateral cephalometric radiographs of 31 low angle, 40 high angle and 33 normal growth subjects with Class I malocclusion were examined. Nasopharyngeal airway space and upper airway measurements were larger and palatal tongue space was narrower in low angle than in high angle subjects.

\section{NORMAL SUBJECTS VS CLASS II MALOCCLUSION:}

Studies done among Class I and Class II subjects. In all the study Class II patients were compared with Class I patients and results were concluded. The results stated that the Class II subjects had a smaller dimensions of pharyngeal airway compared to that of Class I subjects.

MERGEN AND JACOBS [1] undertook a study to determine whether any relationship exist between normal occlusion and any dental malocclusion.20 subjects with normal occlusion and 20 subjects with class II malocclusion were considered in the study. They concluded that the nasopharyngeal dimension was larger in normal occlusion than in class II subjects and convexity of the posterior nasopharyngeal wall was more prevalent in class II cases.

F.A SOSA [2] reported that the post pharyngeal lymphoid tissue in Class I and Class II malocclusion. His study suggested that there was not any clear cut relationship between either Class I or Class II Div I Malocclusion and total pharyngeal area.

JOHN.KERR [3] Compared Class I and Class II malocclusion. He suggested that the pharyngeal airway was retruded in class II compared to class I

DE FREITAS MR, ALCAZAR NM, [7] stated that the subjects with Class I and Class II malocclusions and vertical growth patterns have significantly narrower upper pharyngeal airways than those with Class I and Class II malocclusions and normal growth patterns. The sample comprised 80 subjects divided into 2 groups: 40 Class I and 40 Class II, subdivided according to growth pattern into normal and vertical growers. 
IFFAT BATOOL Et Al 2010 [13] Compared the pharyngeal airway space in class II low angle and high angle case. They suggested that Subjects with Class II malocclusions and vertical growth patterns have significantly narrower upper and lower pharyngeal airways than those with Class II malocclusions and horizontal growth patterns.

\section{NORMAL SUBJECTSVS CLASS III MALOCCLUSION:}

Studies done among Class I and Class III subjects. In all the study Class III patients were compared with Class I patients and results were concluded. The results stated that the Class III subjects had a larger dimensions of pharyngeal airway compared to that of Class I subjects.

\section{- In 2009 TOMONORI IWASAKIHARUAKI} HAYASAKI [11] used cone-beam computed tomography for evaluating the pharyngeal airway, The sample comprised 45 children (average age, 8.6 \pm 1.0 years) divided into 2 groups: 25 with Class I and 20 with Class III malocclusions. They concluded that The Class III malocclusion is associated with a large and flat OA compared with the Class I malocclusion.

- MARTIN AND MUELAS [18] Did a comparative study of nasopharyngeal soft tissue characteristic in Class III malocclusion patients. A sample of 71 patients with class III malocclusion were selected. This study suggests new lines of investigation about the relationship between skeletal and dental anomalies and airway obstruction.

\section{CLASS I vs, CLASS II vs CLASS III MALOCCLUSION:}

A study on the pharyngeal size in different skeletal patterns were assessed. The different skeletal patterns were compared with Class I .The studies were:

- CELYEN AND OKTAY. [4] A cephalometric study of the pharyngeal size was investigated in 90 subjects, 45 males and 45 females, having different ANB angles. All of the subjects were aged 13 to 15 years. It was observed that the oropharynx area became smaller with the increase of ANB angle.

- ABU ALLHAIJA, AL-KHATEEB [6] the study was to investigate the uvulo-glosso-pharyngeal dimensions in subjects with different anteroposterior jaw relationship. Cephalometric radiograph of 90 subjects (45 females and 45 males, aged 14-17 years) were divided into three groups,Class I, class II and class III. They concluded that In conclusion, uvuloglossopharyngeal dimensions are affected by anteroposterior skeletal pattern

- T.MUTO [10] reported that the anteroposterior bphaygeal airway space was larger in mandibular prognathism and smaller in mandibular retrognathic.

- DAN GRAUER, LUCIA S.H.CEVIDANES [12], Pharyngeal airway volume and shape was assessed using Cone beam Computed Tomography. It was found in relationship with facial morphology. They concluded that the Skeletal class II had forward inclination of airway and Class III subjects had more vertically oriented airway.

- YOON-JI KIM [14] et al compared the pharyngeal airway form in 3 dimensional in children with different anteroposterior pattern.60 healthy children were divided in three groups by different anteroposterior jaw relationship. He found that the Class II malocclusion has more backward orientation and smaller volume of the pharyngeal airway than do of children with class I and class III malocclusion.

- KYUNG-MIN OHA [15] 3- d Analysis of the pharyngeal airway in preadolescent children with different anteroposterior skeletal pattern was studied by 27 healthy children were considered in the study and an analysis were derived. They concluded that Retrognathic children has a smaller pharyngeal airway compared normal children.

- HASAN ET AL [19] conducted a study to evaluate the nasalpassage (NP) and oropharyngeal (OP) volumes of patients with different dentofacial skeletal patterns. Methods: The study sample consisted of 140 patients (70 boys, 70 girls), divided into 3 groups as Class I, Class II, and Class III. The OP airway volumes of Class II patients were smaller when compared with Class I and Class III patients.

\section{Discussion}

Ever since Broadbent found out Radiograph in 1918, its being used for diagnosis in various medical field. Roentgenography and Cephalometrics has provided the orthodontist with an ability to see beneath soft tissue, which gave them greater insight into most of the hard and soft anatomical structures that contribute to the facial growth. Pharyngeal airway dimension is a area of interest for many authors. Many articles were published to explore the relationship between nasopharyngeal airway and craniofacial growth. The advancement of newer technologies lead to more precise finding of the nasopharyngeal airway and its relationship. Newer advancements like Cone Beam Computed Tomography (CBCT) explored the pharyngeal relationship in a 3Dimensional view.

On the other hand Malocclusion is of greatest concern for an orthodontist. Malocclusion is any perversion of normal occlusion of the teeth. Many classification were put forward for describing malocclusion. The most accepted classification for malocclusion was given by EDWARD ANGLE.

Retrognathic Mandible is a common feature in class II malocclusion.

Prognathic mandible is a common feature in Class III malocclusion [14]

The relationship of the pharyngeal airway dimensions with different malocclusion was found early back 1970 by KERR 3 who compared the pharyngeal airway among class I and class II subjects(The nasopharynx, Face height and overbite). Then lot of relevant studies were published and comparison was done with different malocclusion.

Opinions differ with regard to the relationship of pharyngeal airway and type malocclusion [11,12,13,14,15].

Ceylan and Oktay [4] reported that the changes in the ANB angle affected nasopharyngeal airway size and that the oropharyngeal space.

Joseph et al reported that the nasopharyngeal airway in hyperdivergent individuals was significantly narrower than that of normodivergent individuals. 
Kerr [3] reported that the class II malocclusion subjects showed narrow nasopharyngeal airway compared with class I and normal occlusion.
Muto [10] reported with a smaller airway space in mandibular retrognathism than in normal individuals.

Table 1.

\begin{tabular}{|c|c|c|c|c|c|}
\hline $\begin{array}{l}\text { Authors name } \\
\text { and year }\end{array}$ & $\begin{array}{l}\text { Name of the } \\
\text { Journal }\end{array}$ & Sample size & $\begin{array}{l}\text { Methods } \\
\text { used }\end{array}$ & $\begin{array}{c}\text { Comparision } \\
\text { between }\end{array}$ & Results outcome \\
\hline $\begin{array}{c}\text { C. Mergen et al } \\
1970 \\
\end{array}$ & $\begin{array}{c}\text { Angle } \\
\text { orthodontist }\end{array}$ & $\begin{array}{l}\text { Females-40 } \\
\text { Age - 13-14yrs }\end{array}$ & $\begin{array}{c}\text { Lateral } \\
\text { cephalogram }\end{array}$ & Class I and Class II & $\begin{array}{l}\text { Class II found To have smaller } \\
\text { dimension }\end{array}$ \\
\hline $\begin{array}{l}\text { Sosa, Graber } \\
1982\end{array}$ & Ajo-Do & $\begin{array}{c}2 \text { groups- male and female } \\
144 \text { patients- } 46 \text { female and } 34 \\
\text { males } \\
\text { Age }-7 \text { to } 12 \text { yrs }\end{array}$ & $\begin{array}{c}\text { Lateral } \\
\text { cephalogram }\end{array}$ & $\begin{array}{c}\text { Class } \\
\text { I and Class II }\end{array}$ & $\begin{array}{l}\text { Class II airway space smaller } \\
\text { compared to normal subjects }\end{array}$ \\
\hline $\begin{array}{c}\text { John.C.Kerr } \\
1985\end{array}$ & $\begin{array}{c}\text { Angle } \\
\text { orthodontist }\end{array}$ & $\begin{array}{c}44 \text { males, } \\
\text { Age: } 5,10,15 y r s\end{array}$ & $\begin{array}{c}\text { Lateral } \\
\text { cephalogram }\end{array}$ & Class I and Class II & $\begin{array}{l}\text { Class II found To have smaller } \\
\text { dimension }\end{array}$ \\
\hline $\begin{array}{l}\text { Ismall ceylan } \\
1995\end{array}$ & Ajo -Do & $\begin{array}{c}\text { Total- } 90 \\
45 \text { male } \\
45 \text { female } \\
\text { Age } 13-15 \text { yrs }\end{array}$ & $\begin{array}{c}\text { Lateral } \\
\text { cephalogram }\end{array}$ & $\begin{array}{l}\text { Class I, Class II } \\
\text { and Class III }\end{array}$ & $\begin{array}{l}\text { Different class has different } \\
\text { pharyngeal airway dimension. }\end{array}$ \\
\hline $\begin{array}{l}\text { Abu A.Joseph } \\
1998\end{array}$ & $\begin{array}{c}\text { Oral } \\
\text { Maxillofacial } \\
\text { Surgery journal }\end{array}$ & $\begin{array}{c}\text { Total no:50 } \\
\text { Normodivergent:23 } \\
\text { Hyperdivergent:27 } \\
\end{array}$ & $\begin{array}{c}\text { lateral } \\
\text { cephalogram }\end{array}$ & Class I and Class II & $\begin{array}{l}\text { Hyperdivergent patients } \\
\text { narrower than normodivergent }\end{array}$ \\
\hline $\begin{array}{l}\text { Elham Saleh } \\
2005\end{array}$ & $\begin{array}{l}\text { Angle } \\
\text { orthodontist }\end{array}$ & $\begin{array}{l}\text { Total group-90 } \\
45 \text {-Female } \\
\text { 45-male } \\
\text { Age }-14-17 \text { yrs }\end{array}$ & $\begin{array}{c}\text { Lateral } \\
\text { cephalogram }\end{array}$ & $\begin{array}{l}\text { Class I, ClassII and } \\
\text { Class III }\end{array}$ & $\begin{array}{l}\text { Different class had different } \\
\text { dimensions }\end{array}$ \\
\hline $\begin{array}{l}\text { Marcos Roberto } \\
2006\end{array}$ & Ajo-Do & $\begin{array}{c}2 \text { groups } \\
40 \text { class I } \\
40 \text { ClassII } \\
\text { Age } 11.6 \text { yrs } \\
\end{array}$ & $\begin{array}{c}\text { Lateral } \\
\text { cephalogram }\end{array}$ & Class I and Class II & $\begin{array}{l}\text { Upper airway long in } \\
\text { classII,and lower airway short } \\
\text { compared to ClassI }\end{array}$ \\
\hline $\begin{array}{l}\text { Oscar Martin } \\
2006\end{array}$ & Ajo-Do & $\begin{array}{c}\text { A sample of } 91 \text { patients. } \\
\text { 55-men } \\
\text { 36- female } \\
\text { Age - } 26 \text { yrs }\end{array}$ & $\begin{array}{c}\text { Lateral } \\
\text { cephalogram }\end{array}$ & Class I & $\begin{array}{l}\text { No relavent identification } \\
\text { observed. }\end{array}$ \\
\hline $\begin{array}{l}\text { Yu Kikuchi } \\
2008\end{array}$ & Bull Tokoyo & $\begin{array}{c}25 \text { adult women } \\
\text { Age }-22 y r s\end{array}$ & СBCT & $\begin{array}{l}\text { Different facial } \\
\text { morphology }\end{array}$ & $\begin{array}{l}\text { Airway is influence by facial } \\
\text { morphology }\end{array}$ \\
\hline $\begin{array}{l}\text { T.Muto } \\
2008\end{array}$ & $\begin{array}{l}\text { Oral and } \\
\text { maxillofacial }\end{array}$ & $\begin{array}{c}\text { Female } \\
\text { Total }-30 \\
\text { Age } 22.7 \text { yrs } \\
\end{array}$ & $\begin{array}{c}\text { Lateral } \\
\text { cephalogram }\end{array}$ & Class I and ClassII & $\begin{array}{l}\text { Smaller airway in retrognathic } \\
\text { mandible }\end{array}$ \\
\hline $\begin{array}{l}\text { TomonoriIwasaki } \\
2009\end{array}$ & Ajo-Do & $\begin{array}{c}45 \text { children(girls and boys) } \\
2 \text { groups- } 25 \text { class I } \\
20-\text {-Class III } \\
\text { Age } 11.5-13 \text { yrs } \\
\end{array}$ & СBCT & $\begin{array}{l}\text { Class I and Class } \\
\text { III }\end{array}$ & $\begin{array}{l}\text { Class III has larger } \\
\text { oropharyngeal dimension }\end{array}$ \\
\hline $\begin{array}{l}\text { Dan Grauer } \\
2009 \\
\end{array}$ & Ajo-Do & 62 non growing patients. & СBCT & Facial morphology & Airway space is changed. \\
\hline $\begin{array}{l}\text { Liffat batool } \\
2010\end{array}$ & $\begin{array}{l}\text { Pak dental } \\
\text { journal }\end{array}$ & $\begin{array}{l}\text { The sample comprised sixty five } \\
\text { class II subjects divided into } 2 \\
\text { groups: thirty three Class II high } \\
\text { angle and thirty two Class II low } \\
\text { angle }\end{array}$ & $\begin{array}{c}\text { Lateral } \\
\text { cephalogram }\end{array}$ & $\begin{array}{l}\text { Class II -High } \\
\text { angle and Class II- } \\
\text { Low angle. }\end{array}$ & $\begin{array}{l}\text { Class II pharyngeal airway is } \\
\text { smaller in vertical growth cases. }\end{array}$ \\
\hline $\begin{array}{l}\text { Yoon-ji-kim } \\
2010\end{array}$ & $\begin{array}{l}\text { Angle } \\
\text { orthodontist }\end{array}$ & $\begin{array}{c}27 \text { healthy children } \\
12 \text { boys } 15 \text { girls } \\
\text { Age-11yrs } \\
\end{array}$ & СBCT & $\begin{array}{l}\text { ClassI, Class II and } \\
\text { ClassIII }\end{array}$ & $\begin{array}{c}\text { Retrognathic was significantly } \\
\text { smaller than healthy } \\
\text { individuals. }\end{array}$ \\
\hline $\begin{array}{l}\text { Kyung-Min } \\
2011\end{array}$ & $\begin{array}{c}\text { Angle } \\
\text { orthodontist }\end{array}$ & $\begin{array}{c}60 \text { healthy children } \\
\text { 3groups-ClassI,II,III } \\
\text { Age-11.9-12. } \\
\end{array}$ & СВCТ & $\begin{array}{l}\text { Class I,ClassII and } \\
\text { ClassIII }\end{array}$ & $\begin{array}{l}\text { Class II the oropharyngeal } \\
\text { airway is bigger }\end{array}$ \\
\hline $\begin{array}{l}\text { Faruk Izzet Ucara } \\
2011\end{array}$ & $\begin{array}{c}\text { Angle } \\
\text { orthodontist }\end{array}$ & $\begin{array}{c}31 \text { low angle } \\
40 \text { high angle } \\
\text { Male and female } \\
\text { Age 14-15yrs } \\
\end{array}$ & $\begin{array}{c}\text { Lateral } \\
\text { cephalogram }\end{array}$ & Among Class I & $\begin{array}{c}\text { Orofacial airway dimensions in } \\
\text { subjects with Class I } \\
\text { malocclusion and different } \\
\text { growth patterns is identified }\end{array}$ \\
\hline $\begin{array}{l}\text { Yoshihiko } \\
2011\end{array}$ & $\begin{array}{l}\text { Angle } \\
\text { orthodontist }\end{array}$ & $\begin{array}{c}25 \text { girls with prognathism } \\
15 \text { girls with normal occlusion } \\
\text { Age 8.5-9.5 yrs }\end{array}$ & $\begin{array}{c}\text { Lateral } \\
\text { cephalogram }\end{array}$ & Among class I & $\begin{array}{l}\text { Prognathism has larger } \\
\text { pharyngeal space }\end{array}$ \\
\hline $\begin{array}{l}\text { Oscar martin } \\
2011\end{array}$ & AJO-DO & $\begin{array}{c}62 \text { patients(boys and girls) } \\
2 \text { groups- } \\
\text { Class I-91 } \\
\text { Class III-71 } \\
\end{array}$ & $\begin{array}{c}\text { Lateral } \\
\text { cephalogram }\end{array}$ & $\begin{array}{l}\text { ClassI and } \\
\text { Class III }\end{array}$ & Class III was larger airway \\
\hline $\begin{array}{l}\text { Hakan El } \\
2011\end{array}$ & Ajo-DO & $\begin{array}{l}140 \text { patients ( } 70 \text { boys, } 70 \text { girls), } \\
\text { divided into } 3 \text { groups as Class I } \\
\text { and class II and class III. }\end{array}$ & $\begin{array}{c}\text { Lateral } \\
\text { cephalogram }\end{array}$ & $\begin{array}{l}\text { Class I ,ClassII and } \\
\text { ClassIII }\end{array}$ & $\begin{array}{l}\text { ClassIII upper airway was } \\
\text { smaller. }\end{array}$ \\
\hline
\end{tabular}

dimensions are subjected to change with retrognathic

\section{Conclusion}

manbible and prognathic mandible comparing with normal mandible.

With the above referred study the pharyngeal airway is sensitive to different anteroposterior. The Airway 
[1] The size of the Nasopharynx associated with normal occlusion and Class II malocclusions (Angle orthodontist 1970).

[2] Post pharyngeal Lymphoid tissue in class I and class II(Sosa,Graber and Muller) AJO- DO 1982.

[3] The nasopharynx, Face height and overbite (W. John .Kerr) Angle orthodontist 1985.

[4] A study on the pharyngeal size in different skeletal pattern (Ismall ceylan) AJO-DO 1995.

[5] A cephalometric comparative study of the soft tissue airway dimension in persons with hyperdivergent and normodivergent facial pattern(Oral Maxillofacial Surgery) 1998.

[6] Uvulo-glosso-pharyngeal dimensions in different anteroposterior skeletal patterns.( Angle Orthod. 2005 Nov Elham Saleh Abu Allhija.

[7] Upper and lower pharyngeal airways in subjects with Class I and Class II malocclusions and different growth patterns. (Am J Orthod Dentofacial Orthop. 2006 Dec).Marcos Roberto de freitas.

[8] Nasopharyngeal cephalometric study of ideal occlusion.(Am J Orthod Dentofacial Orthop. 2006 Oscar Martin.

[9] Three dimensional relationship between pharyngeal airway and maxilla facial morphology(Bull Tokoyo dental coll)Yu Kikuchi 2008.

[10] A Cephalometric evaluation of the pharyngeal airway space in patients with mandibular retrognathia and prognathia and normal subjects(Oral and Maxillofacial Surgery)2008-T.Muto.

[11] Oropharyngeal airway in children with Class III malocclusion evaluated by cone-beam computed tomography (AJO-DO 2009) Tomonori IwasakiHaruaki Hayasaki.

[12] Pharyngeal airway volume and shape from cone-beam computed tomography: Relationship to facial morphology (AJO-DO Dan GrauerLucia S.H. Cevidanes).
[13] Comparison of upper and lower pharyngeal airway space in class ii high and low angle cases(pak dental journal 1iffat batool).

[14] Three Dimensional analysis of pharyngeal airway in preadolescent children with different skeletal pattern( AJO-DO 2010 Yoon-jikim).

[15] Three-dimensional analysis of pharyngeal airway form in children with anteroposterior facial patterns.(Angle orthodontist KyungMin Oha; Ji-Suk Honga).

[16] Orofacial airway dimensions in subjects with Class I malocclusion and different growth patterns ( Angle orthodontist Faruk Izzet Ucara) 2011.

[17] Pharyngeal airway in children with prognathism and normal occlusion (Angle orthodontist Yoshihiko Takemotoa 2011).

[18] Comparative study of nasopharyngeal soft tissue in characteristic in patients with class III malocclusion (AJO-DO Oscar martin 2011).

[19] Airway volume for different dento facial skeletal patterns Hakan El and Juan Martin Palomo. Am J Orthod Dentofacial Orthop 2011.

[20] Cephalometric evaluation and measurement of upper airway(Seminar in Orthodontics) 2004.

[21] Lateral cephalometric analysis of the pharyngeal airway space affected by head posture.(Int Journal Oral Maxillofacial Surgery 2008).

[22] A comparison study of upper airway among different skeletal craniofacial patterns in non snoring Chinese children.( Angle Orthod. 2010).

[23] Nasopharyngeal and facial dimension of different morphological pattern (Dental press journal-2010 Murilo Fernando). 